\title{
COVID-19 Vaccine Hesitancy on Society and Related Legal Regulations
}

\author{
Irzal Rakhmadhani ${ }^{1}$, Erna Yulida ${ }^{2}$, Fahrina $^{3}$, Abdul Kadir Jaelani ${ }^{4}$ \\ ${ }^{1,2,3}$ District Health Office of Hulu Sungai Utara, South Kalimantan, Indonesia \\ ${ }^{4}$ Universitas Sebelas Maret, Surakarta, Indonesia \\ irzal.rakhmadhani@gmail.com
}

\begin{abstract}
In order to overcome the COVID-19 pandemic, all countries throughout the world are prioritizing COVID-19 vaccination. Vaccination is the key to achieving herd immunity in society and reducing COVID-19-related morbidity and mortality. However, the COVID-19 vaccination process in Indonesia is running slowly due to public refusal of vaccines. The Indonesian government has issued various legal actions related to COVID-19 vaccines in society. However, this legal action has caused public controversy, especially in the aspect of providing sanctions for those who refuse the vaccination. The purpose of this study is to look into the reasons for COVID-19 vaccine hesitancy in society, as well as the impact of legal acts that regulate vaccination in increasing vaccination coverage. These research methods are scoping review and normative juridical with statute approach and conceptual approach. Some of the causes of vaccination rejection in society are hesitations of safety, effectiveness, side effects after vaccination, distrust of vaccinations in general, and religious factors. The legal regulations have helped increase community vaccination participation. Presidential Regulation No. 14 of 2021 has regulated mandatory vaccination for those who have met the criteria for COVID-19 vaccination. The Minister of Public Health's Decree No. HK.01.07/MENKES/4638/2021 regarding Technical Guidelines for Vaccination Implementation in the Context of Overcoming the COVID-19 Pandemic establishes the conditions for vaccine recipients to ensure recipients' safety by looking to the individual health status of COVID-19 vaccine recipients. Effective communication strategies and behavioral change interventions for vaccine recipients are needed to reduce public refusal.
\end{abstract}

Keywords-COVID-19 Vaccination, Vaccine Hesitancy, Legal Regulations.

\section{INTRODUCTION}

Coronavirus Disease 2019 (COVID-19) has emerged as a serious public health concern around the world since the World Health Organization (WHO) proclaimed the novel coronavirus outbreak a global pandemic on March 11, 2020. Despite the fact that the Indonesian government has made numerous efforts to overcome the issue, difficulties continue to develop in a lot of different areas. Several initiatives have been undertaken, including the introduction of health protocols, the imposition of Community Activity Restrictions (PPKM), and the accelerated vaccination against COVID-19. Given the fact that health protocols alone are ineffective in reducing morbidity and mortality rates, the COVID-19 vaccination is the most effective method of stopping the cycle of disease transmission.

The COVID-19 vaccine was created successfully after months of study by researchers from numerous countries. Indonesia has begun vaccinated against COVID-19 since the 13th of January 2021, with cross-sectoral engagement in the vaccination campaign. By August 14, 2021, however, only 53,992,005 (25.92 percent) of the total number of first dose vaccines had been given [1]. The low vaccination coverage is attributed to a variety of obstacles encountered during the introduction of the COVID-19 vaccine, particularly public hesitation against vaccinations. The reasons for COVID-19 vaccination refusal and doubts in Indonesian communities have been examined in a number of different research. This is dependent on how the general population perceives the impact of COVID-19 on their health and socio-demographic variables, such as age, level of education, and occupation, among other things [2].

The Indonesian Ministry of Health, in collaboration with the United Nations International Children's Emergency Fund (UNICEF), the Indonesian Technical Advisory Group on Immunization (ITAGI), and the World Health Organization (WHO), is conducting a survey to determine whether the COVID-19 vaccine will be accepted by 115,000 respondents in Indonesia (September 2020). According to the study results, 65 percent of individuals interviewed consented to receive the COVID-19 vaccine, just 8 percent refused to accept the COVID-19 vaccine, and the remaining 27 percent expressed concerns about the COVID-19 vaccine program [2]. It is possible that the current findings will differ from those of the past since the public is more informed about the nature, availability, and safety profile of the COVID-19 vaccine than in the past.

Worldwide, vaccine hesitation is mostly due to concerns about safety, effectiveness, and potential side effects, as well as religious considerations, the impact of one's surrounding environments, and a preference for other alternatives such as natural ingredients. Within each and every group, there are a number of primary causes for doubt. COVID-19 vaccine hesitation in Indonesia is primarily influenced by worries about safety (30\%), effectiveness (22\%), and distrust of all vaccinations (13\%), 
with concerns about side effects such as fever and pain (12\%), as well as religious considerations (8\%) [2].

Vaccine hesitancy continues to be the most significant barrier to controlling the COVID-19 pandemic, despite various evidence that demonstrates the safety and effectiveness of the COVID-19 vaccine. Getting 40 percent of Indonesia's population to obtain vaccines by the end of this year, and increasing that number to 70 percent by the middle of next year, will be a difficult task to accomplish. Indonesian President Joko Widodo issued Presidential Regulation No. 14 of 2021, which says that persons who have been registered as vaccine recipients by the Ministry of Health must be required to receive vaccinations [3]. This approach is consistent with the policies of other countries' governments, which impose vaccination mandates in order to protect the health and safety of individuals and communities worldwide.

The issuing of this presidential regulation has elicited both positive and negative reactions from people of the country. A number of people argued over whether vaccination is a right or an obligation for the general public. Several human rights activists have said unequivocally that refusing vaccinations is a fundamental human right. All sides presented arguments based on scientific facts, which only added to the complexity of the vaccine campaign. As a result, we investigated the factors that contribute to COVID-19 vaccine hesitancy in the community, the impact of legislative rules that regulate vaccination on improving vaccination coverage, and the most effective way to minimize COVID-19 vaccine hesitancy in the Indonesian population.

\section{RESEARCH METHOD}

We conducted a scoping review and normative juridical studies regarding the acceptance of COVID-19 vaccination in Indonesia and related legal regulations. The researcher searched related literature through Google Scholar with the keywords "vaccine", "COVID-19", "hesitancy", "refusal", "vaccination", "coronavirus", "Indonesia". Relevant research data in Indonesia were collected and analyzed. The legal aspect was evaluated through the exploration of secondary legal materials with a statute approach and conceptual approach.

\section{FINDINGS AND DISCUSSION}

Eight researchers from various regions in Indonesia include the final pool of studies. The number of respondents in each study varied from 37 to 112.888 participants. The prevalence of vaccine hesitancy in Indonesia ranges from $10.5 \%$ to $88.5 \%$. Participants in this study varied in age, gender, education level, income, occupation, religion, ethnicity, and marital status. Indonesia's Ministry of Health, ITAGI, UNICEF, and
WHO collaborated on the largest study before the COVID19 vaccine was available [2].

The hesitation of COVID-19 vaccination was primarily due to safety, efficacy, and potential side effects $(>50 \%)$. Another cause is distrust of all vaccines; COVID-19 doubts (the disease does not exist or is not as severe as reported); religious reasons (halal content of vaccines); and fear of being infected with COVID-19. The results were influenced by the characteristics of the participants, the period of the study, the number of cases confirmed and deaths at the study site. Acceptance of COVID-19 vaccination is also depended upon the role of the government and applicable legal regulations when this study was conducted [2, 4-10].

\section{TABLE 1 REASONS FOR COVID-19 VACCINE HESITANCY IN INDONESIA}

\begin{tabular}{|c|c|c|}
\hline $\begin{array}{c}\text { Author/Period/ } \\
\text { Sample Size }\end{array}$ & $\begin{array}{l}\text { Hesitancy } \\
\text { Rate }\end{array}$ & $\begin{array}{c}\text { Reasons for The Vaccine } \\
\text { Hesitancy }\end{array}$ \\
\hline $\begin{array}{l}\text { Ministry of } \\
\text { Health, ITAGI, } \\
\text { UNICEF, and } \\
\text { WHO/2020/ } \\
112.888[2]\end{array}$ & $35,2 \%$ & $\begin{array}{l}\text { Vaccine safety }(30 \%) \text {, vaccine } \\
\text { effectiveness }(22 \%) \text {, vaccine } \\
\text { disbelief }(13 \%) \text {, side effects } \\
(12 \%) \text {, religious reasons }(8 \%)\end{array}$ \\
\hline $\begin{array}{l}\text { Valinza, V / } \\
2021 \text { / } 61 \text { [4] }\end{array}$ & $88.5 \%$ & $\begin{array}{l}\text { There is no relationship } \\
\text { between knowledge level and } \\
\text { vaccination readiness }\end{array}$ \\
\hline $\begin{array}{l}\text { Argista / } 2021 / \\
440[5]\end{array}$ & $22,3 \%$ & $\begin{array}{l}\text { Anxiety about the side effects } \\
(43 \%) \text {, the effectiveness of } \\
\text { vaccines (32\%), anxiety about } \\
\text { being exposed to COVID-19 } \\
(28 \%) \text {, religious reasons } \\
(22 \%) .\end{array}$ \\
\hline $\begin{array}{l}\text { Vebrielna, N / } \\
2021 / 272[6]\end{array}$ & $40,07 \%$ & $\begin{array}{l}\text { There is a significant } \\
\text { relationship between } \\
\text { knowledge, perception, } \\
\text { severity, benefit, and cues of } \\
\text { action with vaccination } \\
\text { acceptance }\end{array}$ \\
\hline $\begin{array}{c}\text { Febriyanti N, et } \\
\text { al / } 2021 / 37 \\
{[7]}\end{array}$ & $18,9 \%$ & $\begin{array}{c}\text { Anxiety about the side effects } \\
(56.8 \%) \text {, vaccine effectiveness } \\
(21.6 \%) \text {, vaccine safety } \\
(16.2 \%) \text {, vaccine disbelief } \\
(5.4 \%)\end{array}$ \\
\hline $\begin{array}{l}\text { Ichsan DS, et al } \\
/ 2021 / 266[8]\end{array}$ & $64,7 \%$ & Religious reasons \\
\hline $\begin{array}{l}\text { Indriyanti D / } \\
2021 \text { / } 38 \text { [9] }\end{array}$ & $10,5 \%$ & $\begin{array}{l}\text { Anxiety about the side effects } \\
(100 \%)\end{array}$ \\
\hline $\begin{array}{l}\text { Arumsari, et al / } \\
2021 / 200[10]\end{array}$ & $58,1 \%$ & $\begin{array}{l}\text { Vaccine safety }(30 \%), \text { vaccine } \\
\text { effectiveness }(22 \%) \text { and } \\
\text { vaccine disbelief }(13 \%)\end{array}$ \\
\hline
\end{tabular}

\section{Legal Regulations Regarding COVID-19 Vaccination}

Mandatory vaccines in different countries were able to increase the COVID-19 vaccination coverage despite the pros and cons. According to the WHO, the ethics and consequences of this obligation must be addressed by governments. The ethical justification of this regulation is the high rate of mortality due to COVID-19 in relation to 
public health. However, the law must respond to changes in research regarding COVID-19. The freedom to oppose vaccination must be taken into account against the impact of disease transmission on society. The government needs to take various approaches to educate people that the COVID-19 vaccine is proven to reduce mortality and severe symptoms of the disease. Scientific developments carefully evaluate information on vaccines safety and the screening guidelines for the appropriateness of vaccine targets. The mandatory vaccine is the last alternative if the significance of COVID-19 vaccine in this pandemic is not accepted by people.

WHO gives priority to COVID-19 vaccination as the main step in accelerating the handling of the pandemic. WHO ensures the existence of regulations governing the course of vaccination in various countries of the world. In July 2020, the World Health Organization published "The COVID-19 Law Lab," a compilation of 190 countries' legal regulations on the pandemic. The COVID-19 law laboratory stipulates that regulation protects public health while still complying with international standards of human rights.

In Indonesia, the government has issued various regulations related to COVID-19, including for COVID-19 vaccination. We analyzed Presidential Regulation Number 14 of 2021 concerning Amendments to Presidential Regulation Number 99 of 2020 concerning Vaccine Procurement and Vaccination Implementation in the Context of Handling the Coronavirus Disease 2019 (COVID-19) Pandemic as the main legal regulation that has the greatest impact on COVID-19 vaccination coverage in Indonesia. This Presidential Regulation directly regulates COVID-19 vaccination activities in Indonesia, starting from the procurement of vaccines until the implementation of vaccination activities. Based on this regulation, the Ministry of Health set to targets people that required to participate in COVID-19 vaccination. The Indonesian Ministry of Health had asked for recommendations and considerations from BPOM, ITAGI, and health professional organizations before setting targets. Therefore, the vaccination target was approached in stages in accordance with safety principles and the most recent scientific knowledge present at the time of writing. One example is the target vaccine, which only included adolescents, the elderly, pregnant women, and lactating mothers after receiving recommendations from healthcare professionals' organizations $[11,12]$.

The Ministry of Health, in its capacity as the organization in charge of vaccination activities, has the authority to determine: (a) Criteria and priorities for vaccine recipients, specifically the eligibility criteria for vaccination targets during screening, as recommended by health professional organizations; (b) Prioritization of vaccine recipient areas based on epidemiological data on morbidity and mortality in each region; (c) vaccine administration schedule and stages in the form of phases of national immunizations (priority to health workers, public service workers, and geriatric groups before targeting the general population), as well as intervals between vaccination doses; (d) Service standards for vaccination in the form of vaccination service flow, record-keeping, reporting, and management of vaccination logistics and vaccine cold chain are all included. [3].

The vaccine against COVID-19 is required for all targets specified by the Ministry of Health, according to Article 13A paragraph (2) of the Constitution. In the event that a person does not meet the eligibility requirements for vaccination based on objective screening, the person is not required to be vaccinated as a result of this regulation. This is a regulation that is only rarely known by the general population. Some people believe that this regulation is discriminatory because it does not take into consideration the individual's health situation. Numerous targets, despite the fact that they are objectively deserving and safe to be vaccinated, declined to take part in the vaccination program due to different made-up health concerns. According to Article 13 A paragraph (2), a person who has been designated as a target receiver of the COVID-19 vaccine but does not follow the COVID-19 immunization protocol as outlined in paragraph (4) may be subject to administrative sanctions [3].

2. COVID-19 vaccine hesitancy in the general public: what should be done about it?

Many kinds of research have revealed that there are a variety of factors contributing to community hesitation about the COVID-19 vaccine. It is vital to investigate these factors. The government must first ensure that Indonesia's vaccination targets are aware of the safety and efficacy of vaccines before proceeding with the program. The results of BPOM's safety and effectiveness tests must be presented to community leaders who have been vocal in their opposition to vaccines despite the lack of scientific evidence to support their position. Consider the fact that spreading and believing false information regarding vaccines is far easier than making an effort to convey the facts. Despite the fact that vaccination is being used as a method of public health protection, the safety test is still being carried out. The Ministry of Health must persuade the public that the vaccine was not manufactured at random and that all protocols were adhered to in the production of the vaccination.

Concerning Adverse Events Following Immunization (AEFI) can be minimized by addressing various misleading information that is presently spreading. Each health facility has its own AEFI reporting flow, which extends 
from the local to the national level. Any immunized community receives a contact number for medical workers who can be called if they encounter a follow-up incident following immunization. In order for the AEFI committee to assure the authenticity of severe AEFI reports, AEFI reporting must be done with clear and verifiable data. More than 4.9 billion doses of vaccines have been delivered worldwide as of August 17, 2021 [13]. If the COVID-19 vaccination is found to be unsafe and harmful like a matter of public concern, there should be a large number of victims who have come forward.

\section{The Role of Health Workers and Community Leaders}

In addition to curative (treatment) efforts, health practitioners also undertake promotive and preventive efforts. Medical personnel, particularly those working in the field of COVID-19, play critical responsibilities in educating and convincing the general public to engage in vaccination efforts. A higher understanding of health information by the general people is a goal for any health care provider, whether medical, paramedical, or support services. As a result, when it comes to educating the public, they must keep up with scientific advancement. Health workers must explain how vaccination has been successful in the past in eradicating various diseases such as polio, variola, tetanus, as well as other diseases. Equally a result, COVID-19 vaccination is expected to be as effective as other vaccines in eradicating this disease.

It should be understood that persuading people who are opposed to COVID-19 vaccination will need a significant amount of work on the part of many different groups. A community's involvement and engagement of health workers and influential community leaders in educating individuals about the significance of vaccination may be more effective than other methods of reaching people [14]. The community approach, as implemented by community leaders, must take into account the community's initial viewpoints as well as the primary reasons for their rejection. Following that, a proactive discourse was undertaken through the use of a survey that was carefully structured to avoid misrepresentation. The government can use social media to provide accurate information about the COVID-19 pandemic and the duties and responsibilities of those who may be affected by it.

\section{The Importance of Mandatory Vaccines during a pandemic}

Because all targets who do not have any contraindications to receiving the vaccine will be required to do so, the achievement of COVID-19 immunization will be significantly increased by the mandatory vaccine. When vaccine coverage is low and ineffective at lowering morbidity and mortality during pandemics, the obligatory vaccine is an extreme measure. Due to the increased mortality rate among COVID-19 patients, both in healthcare facilities and in self-isolation facilities, several stakeholders realized that the public's right to health and protection against exposure to this disease had to come first, and that their own interests could not be put aside. However, given the progression of the COVID-19 pandemic, the government must conduct a thorough assessment of vaccination implementation, notably in terms of targeting, vaccine logistics distribution, AEFI management, and legal product changes. Regulations must be consistent with the latest COVID-19 pandemic research, the availability of vaccinations (including their safety, efficacy, and side effects), as well as the results of COVID19 vaccination campaigns in Indonesia. In order to achieve public health and to overcome the pandemic, the government should prioritize public communication tactics, psychological approaches, and mass vaccination campaigns that are more effective and acceptable to the population [15].

\section{CONCLUSION}

Efforts to increase the coverage of COVID-19 vaccination remain to be met with opposition from various parties. The most common causes for vaccine hesitancy around the world are concerns about safety, efficacy, potential side effects, religious beliefs, the influence of the surrounding environment, and a preference for other alternatives such as those derived from natural components, among other factors. Indonesia's government has adopted several legal measures in an attempt to address this issue. Presidential Regulation Number 14 of 2021 has been the most effective legislative regulation in terms of expanding vaccine coverage. It should be noted that the mandatory vaccine stated in this regulation is a last alternative when low COVID-19 vaccination coverage is insufficient to minimize morbidity and mortality due to COVID-19. Although people are deeply worried that the government is unconcerned about the safety and effectiveness of vaccines, this is an unfounded concern. In part because this law assures that mandatory vaccine are only carried to vaccination targets who are a reasonable apprehension of being immunized based on data from the Ministry of Health after taking into consideration recommendations from the WHO, ITAGI, and professional health organizations. The Technical Guidelines for the administration of vaccines have also regulated the flow of reporting and handling of adverse events that may occur in vaccine recipients. The government must employ a public communication strategy, a psychological strategy, and a mass vaccination campaign that is more effective and accepted by the community in addition to avoiding public concerns regarding the COVID-19 vaccine. 


\section{REFERENCES}

[1] Kementerian Kesehatan Republik Indonesia, "Vaksinasi COVID19 Nasional: Data Per Tanggal 14 Agustus 2021 Pukul 18.00 WIB. ,"Vaksin Dashboard, 15-Aug-2021. [Online]. Available: https://vaksin.kemkes.go.id/. [Accessed: 15-Aug-2021].

[2] Kementerian Kesehatan, ITAGI, UNICEF, and WHO, "Survei Penerimaan Vaksin di Indonesia." Kemenkes RI, Jakarta, 2020.

[3] Peraturan Presiden (PERPRES) tentang Perubahan atas Peraturan Presiden Nomor 99 Tahun 2020 tentang Pengadaan Vaksin dan Pelaksanaan Vaksinasi Dalam Rangka Penanggulangan Pandemi Corona Virus Disease 2019 (Covid-19) 2021 (Perpres) 14 (Ind.).

[4] V. Valinza, "Hubungan antara Pengetahuan dengan Kesiapan Penerimaan Vaksinasi dan Pencegahan terhadap COVID-19 pada Masyarakat di 29 Ilir Palembang," dissertation, Universitas Katolik Musi Charitas, Palembang, 2021.

[5] Z. L. Argista, "Persepsi Masyarakat Terhadap Vaksin COVID-19 di Sumatera Selatan," dissertation, Universitas Sriwijaya, 2021.

[6] N. Vabrielna, "Faktor-Faktor yang Berhubungan dengan Penerimaan Masyarakat Terhadap Vaksinasi COVID-19 di Kota Padang Tahun 2021," dissertation, Universitas Andalas, 2021.

[7] N. Febriyanti, M. I. Choliq, and A. W. Mukti, "Hubungan Tingkat Pengetahuan dan Kesediaan Vaksinasi COVID-19 Pada Warga Kelurahan Dukuh Menanggal Kota Surabaya," Seminar Nasional Hasil Riset dan Pengabdian Ke-III (SNHRP-III), pp. 36-42, 2021.

[8] D. S. Ichsan, F. Hafid, K. Ramadhan, and Taqwin, "Determinants of Community Willingness to Receive COVID-19 Vaccination in Central Sulawesi," Poltekita: Jurnal Ilmu Kesehatan, vol. 1, no. 5, pp. 1-11, 2021.

[9] D. Indriyanti, "Perceptions of Public Health Center Officers on the Implementation of COVID-19 Vaccination in the New Normal Era," Jurnal Inspirasi, vol. 12, no. 1, pp. 29-41, 2021.

[10] W. Animsari, R. Desty, and W. Kusumo, "Gambaran Penerimaan Vaksin COVID-19 di Kota Semarang," Indonesian Journal of Health Community, vol. 2, no. 1, pp. 35-45, 2021.

[11] Vaksinasi Tahap 3 Bagi Masyarakat Rentan Serta Masyarakat Umum Lainnya dan Pelaksanaan Vaksinasi COVID-19 Bagi Anak Usia 12-17 Tahun. 2021 (SE) HK.02.02/I/ 1727 /2021 (Ind.).

[12] Surat Edaran Tentang Vaksinasi COVID-19 Bagi Ibu Hamil dan Penyesuaian Skrining dalam Pelaksanaan Vaksinasi COVID-19. 2021 (SE) HK.02.01///2007/2021 (Ind.).

[13] H. Ritchie, E. Mathieu, L. Rodés-Guirao, C. Appel, C. Giattino, E. Ortiz-Ospina, J. Hasell, B. Macdonald, D. Beltekian, and M. Roser, "Coronavirus (covid-19) VACCINATIONS - statistics and research," Our World in Data, 05-Mar-2020. [Online]. Available: https://ourworldindata.org/covid-vaccinations. [Accessed: 21Aug-2021].

[14] E. Dubé and N. E. MacDonald, "How can a global pandemic affect vaccine hesitancy?," Expert Review of Vaccines, vol. 19, no. 10, pp. 899-901, Oct. 2020.

[15] A. A. Dror, N. Eisenbach, S. Taiber, N. G. Morozov, M. Mizrachi, A. Zigron, S. Srouji, and E. Sela, "Vaccine hesitancy: The next challenge in the fight against COVID-19," European Journal of Epidemiology, vol. 35, no. 8, pp. 775-779, Aug. 2020. 